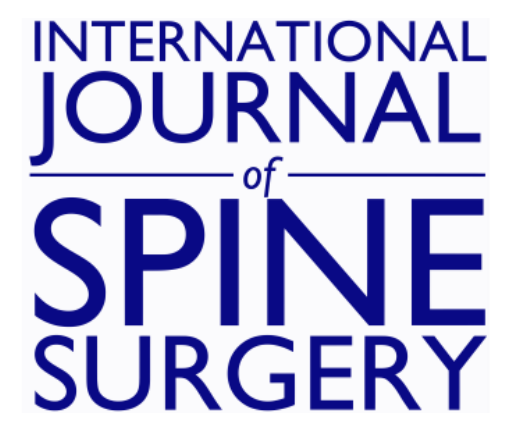

\title{
Cartilage Derived Morphogenetic Protein-2 Induces Cell Migration and Its Chondrogenic Potential in C28/I2 Cells
}

Frank Y. Zhou, Ai-Qun Wei, Bojiang Shen, Lisa Williams and Ashish D. Diwan

Int J Spine Surg 2015, 9 ()

doi: https://doi.org/10.14444/2052

http://ijssurgery.com/content/9/52

This information is current as of April 26, 2023.

Email Alerts Receive free email-alerts when new articles cite this article. Sign up at:

http://ijssurgery.com/alerts

The International Journal of Shing Surgerih 2397 Waterbury Circle, Suite 1,

Aurora, IL 60504, Phone: +1-630-375-1432

(C) 2015 ISASS. All Rights Reserved. 


\section{Cartilage Derived Morphogenetic Protein-2 Induces Cell Migration and Its Chondrogenic Potential in C28/I2 Cells}

Frank Y. Zhou, Ai-Qun Wei, PhD, Bojiang Shen, PhD, Lisa Williams, PhD, Ashish D. Diwan, FRACS, PhD

Department of Orthopaedic Research, Orthopaedic Research Institute, St George Hospital Clinical School, University of New South Wales, Sydney, Australia

\section{Abstract}

Background

Intervertebral disc degeneration is a major cause of low back pain. Previous researches have demonstrated local administration of signalling molecules as potential biological therapies for disc regeneration. Our laboratory has published encouraging results for effectiveness of injection of the cartilage derived morphogenetic protein-2

(CDMP-2) into ovine discs following annular injury. To elucidate the mechanisms underpinning these in vivo effects, this project aimed to investigate the potential of CDMP-2 on cellular migration, proliferation and extracellular matrix production in a human chondrocytic cell line.

\section{Methods}

To evaluate cell motility, cells were seeded into Boyden chambers and CDMP-2 as a chemo-attractant or a stimulant was placed into either the bottom or top chambers respectively. Cells that had completed migration through the porous membrane were visualized by immunocytochemical staining and analysed using Image J. The effect of CDMP-2 on cell proliferation, proteoglycan and collagen production, as well as chondrogenic gene expression in human chondrocytic cell line C28/I2 was also examined.

\section{Results}

The results revealed that cells migrated significantly under the influence of CDMP-2 $(200 \mathrm{ng} / \mathrm{ml})$ stimulation compared to control (3-fold increase, $\mathrm{p}=0.033$ ) and demonstrated a significant chemotactic movement towards a solution of 200ng/ml CDMP-2 (>2-fold increase, $\mathrm{p}=0.027$ ). A 35\% increase in C28/I2 proliferation was observed

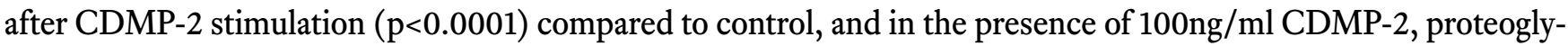
can synthesis had an 8 -fold increase $(\mathrm{p}=0.048)$. Similarly, gene expression analysis demonstrated increased expression of aggrecan, collagen types II, X and XXVII, BMPR-1A and BMPR-2 when cells were treated with CDMP-2.

\section{Conclusion}

The study shows that C28/I2 cells can migrate under the influence of CDMP-2 as a chemoattractant or migration stimulator, suggestive of an effect on chondrocytic cells in the intervertebral disc. Further, CDMP-2 can stimulate C28/I2 cells to proliferate and synthesize key extracellular matrix proteins.

KEYWORDS: INTERVERTEBRAL DISC, DEGENERATIVE DISC DISEASE, EXTRACELLULAR MATRIX, CDMP-2, CELL MIGRATION, CHEMOATTRACTANT VOLUME 9 ARTICLE 52 DOI: 10.14444/2052

\section{Background}

Low back pain is one of the most reported chronic health problems in the adult population..$^{1-3}$ It is rated the $6^{\text {th }}$ most debilitating disease worldwide in terms of disability-adjusted life years (DALYs), and is the leading cause of disability in Australasia and Western Europe. ${ }^{4}$ Degenerative disc disease is one of the major causes of low back pain, with its prevalence estimated at $54 \%$ globally. ${ }^{5}$ The degenerative process of the intervertebral disc (IVD) is initiated by cell- mediated degradation of the nucleus pulposus (NP). ${ }^{6}$ The NP, which lies in the centre of the IVD with a meshwork matrix of proteoglycans, collagens and non-collagenous proteins, maintains disc hydration and mechanical integrity. These matrix components are produced in the NP by a heterogeneous group of notochordal cells, which dominate in early life, and chondrocyte-like cells, which dominate in adult life. It has been suggested that these chondrocyteresembling cells are derived from the thin layer of cartilaginous endplate (EP) that is between the NP 
and the underlying bony vertebral body. ${ }^{7}$

Degenerative changes in the IVD increase the stress on surrounding tissues, and have been suggested to compress and/or sensitize nearby nerve fibres to manifest as low back pain. ${ }^{8,9}$ The current standard for treatment of degenerative disc disease relies on pain relief, but does not address the mechanical or physiological repair of the disc. ${ }^{10}$ Hence, recent studies have explored biological strategies to reverse the pathological state of the cells and depleted extracellular matrix to a more physiological state. A particular strategy that has interested our group is the injection of signaling molecules into the disc to stimulate recruitment of healthy cells from surrounding tissues. Bone morphogenetic proteins (BMPs) are members of the TGF- $\beta$ superfamily that have been of special interest in disc regeneration due to their endogenous potential for chondrogenesis. ${ }^{11}$

Cartilage-derived morphogenetic protein-2 (CDMP-2), otherwise known as growth differentiation factor-6 (GDF-6) or BMP-13, is an endogenous growth factor belonging to the BMP family and plays an important role in chondrocyte regulation. ${ }^{12,13}$ In a comparative study of the effects of all known BMPs and CDMPs, increased collagen accumulation after adenoviral-mediated CDMP2 gene transfer was among the strongest of all BMPs tested, at 2.5-fold of control. ${ }^{14}$ However, the property that has distinguished CDMP-2 from other members of the same family (e.g. BMP-2) is its anti-osteogenic potential. A previous in vitro study highlighted that CDMP-2 inhibited osteogenic differentiation of human bone marrow mesenchymal stromal cells (BM-MSCs), while promoting chondrogenic differentiation, traits that may make CDMP-2 a more promising molecule for IVD therapy development than other betterknown BMPs. ${ }^{15}$

In an in vivo study it was observed that injection of recombinant human (rh) CDMP-2 into ovine IVDs post annular injury resulted in enhanced cellularity in the disc NP tissues, with observable mobilization of cells from the cartilaginous EP to NP. This implied the possibility that CDMP-2 possessed chemotactic properties, attracting chondrocytic cells into the nucleus. ${ }^{16}$ To our knowledge, the migration of na- tive disc cells induced by CDMP-2 has not been recorded previously, but a review of the literature suggests a strong possibility of CDMP-2 having such chemotactic properties ${ }^{17}$ A demonstration of chemotactic ability in CDMP-2 implies that it would not only be therapeutic in mildly-degenerated discs, where the aim is to stimulate the metabolic activity of existing cells, but also in severe degeneration where the nucleus is depleted of cells. This would further enhance the potential of CDMP-2 to replenish the depleted NP and restore function to the degenerated IVD.

The aim of this project was to evaluate and characterise CDMP-2 induced cell migration in chondrocytic cells, as further evidence for the molecule's chemotactic potential. We hypothesised that the addition of CDMP-2 to chondrocytic cells, resembling those found in the cartilaginous EP of native discs, would increase cell migratory behaviour and elevate known chemotactic markers, as well as inducing proliferation and chondrogenic matrix production compared to unstimulated chondrocytes.

\section{Materials And Methods}

\section{Cell culture}

C28/I2 immortalized human chondrocytes, kindly donated by Dr Mary Goldring, ${ }^{18}$ were cultured in 75cm flasks in 1:1 Dulbecco's Modified Eagles Medium (DMEM) /F12 medium (Life technology, Carlsbad, CA, USA) with $10 \%$ (v/v) foetal calf serum (FCS; Life technology) and 1\% (v/v) antibioticsantimycotics (Life technology) at $37^{\circ} \mathrm{C}$ and $5 \% \mathrm{CO}_{2}$ in an atmosphere of $95 \%$ air. The medium was changed every 48 hours. The cells were sub-cultured for experiments after growing to approximately 80-90\% confluence.

\section{Cellular proliferation assay}

The effect of CDMP-2 on the proliferation of chondrocytes was assessed using the CelTitre $96^{\circledR}$ Aqueous one solution proliferation assay (MTS assay, Promega, Madison, WI, USA) as per manufacturer's instructions.

To determine the optimal dose response of CDMP-2 on cell proliferation, $100 \mu$ l of cells $\left(0.5 \times 10^{5}\right.$ cells/ 
$\mathrm{ml}$ ) were seeded into 96-well plates and cultured for 24 hours. The medium were replaced with $200 \mu l$ of growth medium containing CDMP-2 (Recombinant human CDMP-2, PeproTech, Rocky Hill, NJ, USA) at $0 \mathrm{ng} / \mathrm{ml}, 50 \mathrm{ng} / \mathrm{ml}, 100 \mathrm{ng} / \mathrm{ml}, 150 \mathrm{ng} / \mathrm{ml}$, or $200 \mathrm{ng} /$ $\mathrm{ml}$. The plates were incubated for 48 hours, and then $20 \mu l$ of MTS reagent was added to each well. The plates were incubated for a further 2 hours, and measured for absorbance at a wavelength of $490 \mathrm{~nm}$ in a spectrophotometer.

To determine the optimal time points of CDMP-2 on cellular proliferation, cells were seeded as described above, and then treated with $100 \mu \mathrm{l}$ of either the growth medium alone or with $100 \mathrm{ng} / \mathrm{ml} \mathrm{CDMP-2}$. The plates were incubated for 24,48 or 72 hours, at the end of which MTS reagent was added and the absorbance was measured at 490nm in the spectrophotometer. Each experiment was conducted with five different cell culture samples $(n=5)$.

\section{Cell migration}

Migration of C28/I2 cells in vitro was detected using the Boyden chamber assay. To achieve this, cultured cells were treated with the migration medium, consisting of DMEM/F12 medium with 1\%FCS. Cells in $100 \mu$ of migration medium at $1 \times 10^{5}$ cells $/ \mathrm{ml}$ were seeded in the top chamber inserts (8nm pores) of a 24-well Boyden-Chamber plate (Becton and Dickinson, Franklin Lakes, NJ) and cultured in the incubator for 1 hour before being divided for two experiments: chemo-stimulation and chemo-attraction. For chemo-stimulation, cells were incubated for $1 \mathrm{hr}$, then $100 \mu \mathrm{l}$ of migration medium containing $0 \mathrm{ng} / \mathrm{ml}$, $100 \mathrm{ng} / \mathrm{ml}, 200 \mathrm{ng} / \mathrm{ml}$ or $300 \mathrm{ng} / \mathrm{ml}$ of CDMP- 2 was added into the inserts with the seeded cells; $600 \mu$ of migration medium was then added to the bottom wells and the plates were cultured for 48 hours. For chemo-attraction, $100 \mu \mathrm{l}$ of additional migration medium was added to the seeded cells in the top chambers. In the bottom wells, $600 \mu \mathrm{l}$ of migration medium containing $0 \mathrm{ng} / \mathrm{ml}, 100 \mathrm{ng} / \mathrm{ml}, 200 \mathrm{ng} / \mathrm{ml}$ or $300 \mathrm{ng} / \mathrm{ml}$ of CDMP-2 was added. Plates were then cultured at $37^{\circ} \mathrm{C}$ under $5 \% \mathrm{CO}_{2}$ for 48 hours. After the 48-hour period, the inserts were washed with PBS and cells were fixed with $4 \%$ paraformaldehyde for 10 minutes, at the end of which the inserts were washed with PBS. The inserts were inverted and the membranes were stained with $0.2 \%$ Crystal Violet solution (Sigma), visualising the cells on the underside of the membrane (migrated cells). The cells adhering to the top of the membrane (non-migrating cells) were scraped off using cotton swabs. The membranes were air dried, mounted onto glass microscope slides and enclosed with coverslips. Slides were viewed under a Leica light microscope with a digital camera, and 3 images of random locations in each slide were photographed at 10x magnification. Each experiment was duplicated, with total images analyzed being $n=6$.

\section{Alcian blue staining}

Proteoglycan (PG) production was estimated by Alcian blue staining. Briefly, $1 \mathrm{ml}$ of cells $\left(0.5 \times 10^{5}\right.$ cells $/ \mathrm{ml}$ ) were seeded into 6-well plates with glass cover slips in each well and incubated for 24 hours. Cells were then treated with or without $100 \mathrm{ng} / \mathrm{ml}$ CDMP-2 in growth medium for 48 hours. After wash with PBS, cells were fixed with $4 \%$ paraformaldehyde prior to staining with $1 \%$ Alcian blue solution (SigmaAldrich, St. Louis, MO, USA) in 3\% acetic acid for $30 \mathrm{~min}$. The cells were washed with water, air-dried and then examined using a Leica light microscope. Images of 5 random fields in each cover slip were photographed with a Leica camera. Captured images were semi-quantitatively analysed using the software ImageJ to determine the amount of PG present, which was highlighted by the Alcian blue stain. Each experiment was conducted in triplicate $(n=3)$.

\section{Image analysis}

Photographs were saved as jpg files and then opened with ImageJ software (version 1.47i, National Institute of Health, Bethesda, MD, http://rsbweb.nih.gov/ij/). Images were analysed with methodology as highlighted by Gutierrez and colleagues [19].

\section{$\left[{ }^{3} \mathrm{H}\right]$-proline incorporation assay}

Total collagen synthesis was assayed by measurement of cellular [ $\left.{ }^{3} \mathrm{H}\right]$-proline incorporation. Briefly, cultures were treated with or without CDMP-2 $(100 \mathrm{ng} / \mathrm{ml})$ for $48 \mathrm{~h}$ and then $10 \mu \mathrm{Ci} / \mathrm{ml}\left[{ }^{3} \mathrm{H}\right]$-proline (Perkin-Elmer, Life Sciences, Boston, MA) was added to each well for further 12 hours incubation. At the end, cells were washed 3 times with cold PBS 
and incubated with 5\% trichloroacetic acid (TCA) for 30 min. After 2 rinses with cold 5\% TCA, the acidprecipitate material was solubilized overnight with $0.5 \mathrm{ml}$ of $0.5 \mathrm{M} \mathrm{NaOH}$ at $37^{\circ} \mathrm{C}$. Finally, all reactions were stopped by adding $0.5 \mathrm{M} \mathrm{HCl}$, and harvested materials were placed in $2 \mathrm{ml}$ liquid scintillation and measured in a $\beta$-counter (TL 5,000 sec, Beckman Instruments, Inc., Fullerton, CA). The resulting value of collagen synthesis were normalized by total protein and expressed as cpm/ug of protein.

\section{Immunocyłochemical analysis}

Immunocytochemistry was used to observe the functional expression of chondrocytic proteins in C28/I2 cells following CDMP-2 stimulation. $1 \mathrm{ml}$ of cells $(0.5$ $\mathrm{x} 10^{5}$ cells $/ \mathrm{ml}$ ) was seeded into 6-well plates with glass cover slips in each well and incubated for 1 hour. Cells were then stimulated with CDMP-2 $(0 \mathrm{ng} / \mathrm{ml}, 100 \mathrm{ng} / \mathrm{ml}, 200 \mathrm{ng} / \mathrm{ml})$ in growth medium for 48 hours. At the end of culture, cells were fixed with $5 \%$ paraformaldehyde for $15 \mathrm{~min}$ and washed with PBS. Endogenous peroxide activity was depleted with 3\% hydrogen peroxide (Sigma-Aldrich, St. Louis, MO) for $30 \mathrm{~min}$ before blocking for nonspecific binding with $1 \%$ bovine serum albumin (BSA) for $15 \mathrm{~min}$. Cells were then incubated with goat anticollagen-2 polyclonal (1:100; Santa Cruz Biotechnology, Santa Cruz, CA), or mouse anti-aggrecan monoclonal (1:150; Chemicon International, Temecula, CA) primary antibodies for 2 hours. The wells were washed with $0.1 \%$ Triton-X100 in PBS and incubated with MULTILINK solution (DAKO, Botany, Australia) for $15 \mathrm{~min}$ before application of streptavidinconjugated peroxidase incubation for $20 \mathrm{~min}$. The results were visualized with 3,3'-Diaminobenzidine solution (DAKO). Negative controls received identical treatments apart from the omission of the primary antibody. Wells were imaged under a Leica light microscope with a digital camera (Leica DC200, $\mathrm{GmbH}$, Wetzlar, Germany). Five images were captured at random locations in each well and images were analysed using Image in a similar manner to the Alcian blue assay.

\section{Real-time RT-PCR}

C28/I2 cells were cultured in $25 \mathrm{~cm}$ flasks for 48 hours with CDMP-2 stimulated growth media (concentrations of $0 \mathrm{ng} / \mathrm{ml}, 100 \mathrm{ng} / \mathrm{ml}$ and $200 \mathrm{ng} / \mathrm{ml}$ ).
Following culture, total RNA was isolated from the cells using H-RNA purification kits (Roche Diagnostics, Manheim, Germany) as described by the manufacturer. cDNA was generated by reverse transcription of $1 \mu \mathrm{g}$ of total RNA using SuperScript III firststrand synthesis kit (Invitrogen). The cDNA was used in $20 \mu l$ reactions for real-time PCR analysis using a Rotor-Gene RG3000 system (Corbett Life Science, Sydney). The thermal profile for all reactions was as follows: $5 \mathrm{~min}$ at $95^{\circ} \mathrm{C}$, followed by 40 amplification cycles of $15 \mathrm{sec}$ at $95^{\circ} \mathrm{C}, 30 \mathrm{sec}$ at $60^{\circ} \mathrm{C}$ and 15 sec at $72^{\circ} \mathrm{C}$. All primers were designed from published mRNA sequences. The cycle threshold $(\mathrm{Ct})$ value for each reaction as determined, and the relative mRNA expression of various genes was calculated using the Comparative $\mathrm{C}_{\mathrm{T}}$ Method with the average $\mathrm{Ct}$ value of three housekeeping genes- glyceraldehyde-3-phosphate (GAPDH), beta-2-microglobulin (B2M) and hypoxanthine phosphoribosyl-transferase I (HPRT1). The reaction for each gene was repeated four times.

\section{Statistical method}

Statistical analysis was performed using SPPI software (Systat Software Inc., Chicago, IL). The data is expressed as mean \pm standard deviation (SD). Normally distributed data was analysed by Student's TTest and One-way Analysis of Variance (ANOVA). A p-value $<0.05$ was considered significant.

\section{Results}

\section{CDMP-2 stimulates cell proliferation}

C28/I2 cells incubated for 48 hours with culture medium and varying doses of CDMP-2 were analysed using MTS assays. All groups treated with CDMP-2 demonstrated significantly increased absorbance $(\mathrm{p}<0.05)$ compared to control (Figure 1A). In particular, cells treated with $100 \mathrm{ng} / \mathrm{ml}$ of CDMP-2 yielded the highest absorbance, with a 35\% increase compared to control $(\mathrm{p}<0.0001)$. Cells treated with $50 \mathrm{ng} / \mathrm{ml}$ of CDMP-2 yielded the lowest absorbance with a $16 \%$ increase $(\mathrm{p}=0.001)$. The concentration of $100 \mathrm{ng} / \mathrm{ml}$ of CDMP-2 was determined as optimal for the stimulation of cell proliferation and was used for further proliferation and cellular production experiments. 
In determining the proliferation response over time, both the control and CDMP-2 (100ng/ml) groups of cells were cultured for 3 time-points and compared for absorbance. In both the control and CDMP-2 groups, an increase in time was associated with an increase in absorbance (Figure 1B). At 24 hours, CDMP-2 treated cells showed an $18 \%$ increase in absorbance compared to control $(\mathrm{p}=0.046)$. Increased absorbance was most prominent at 48 hours, with the CDMP-2 group having 35\% more absorbance than control $(\mathrm{p}<0.0001)$. There was no significant difference in absorbance at 72 hours when compared to the control ( $\mathrm{p}=0.476)$ (Figure 1B).

CDMP-2 stimulates chondrocyte migration

For migration experiments, $100 \mathrm{ng} / \mathrm{ml}$ and $200 \mathrm{ng} / \mathrm{ml}$ of CDMP-2 were used in comparison to control to establish any dose-response patterns. When
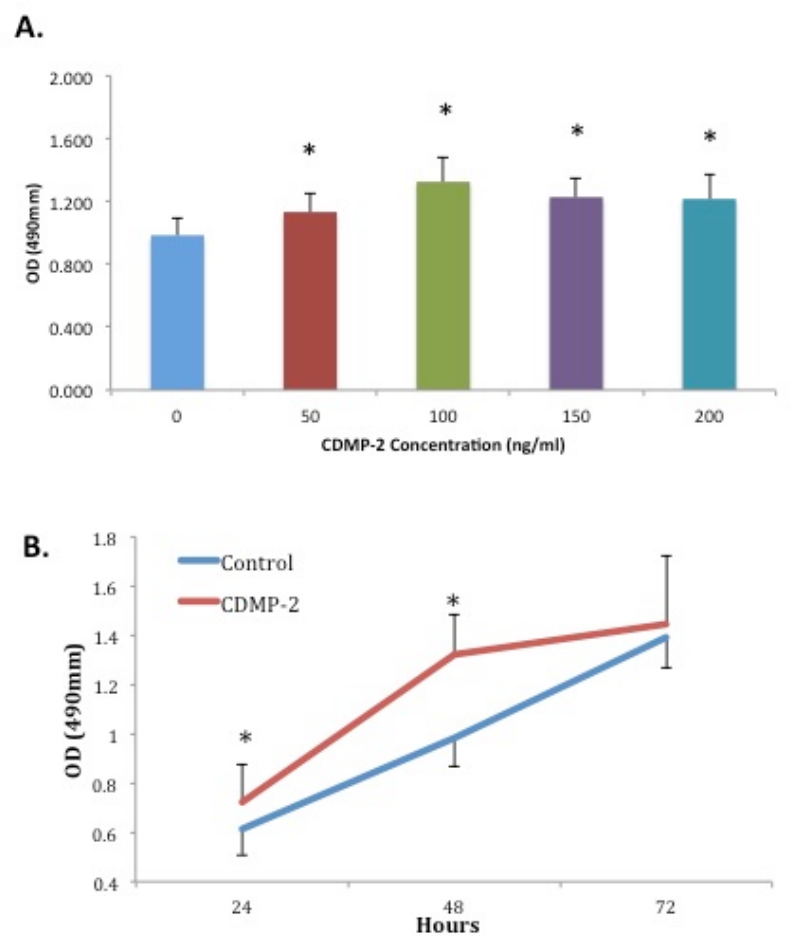

Fig. 1. A) Effect of CDMP-2 on cellular proliferation of $C 28 / 12$ cells at varying doses for 48 hours. Absorbance was significantly higher $(p<0.05)$ in all groups treated with CDMP-2 compared to control. Each bar represents combined data from three individual experiments performed in quintuplicate (mean $\pm S D)$. * indicates significant difference compared with control group $(p<0.05)$. B) Effect of CDMP-2 $(100 \mathrm{ng} / \mathrm{ml})$ on cellular proliferation of $C 28 / 12$ cells at varying times. At 24 and 48 hours, there was significantly higher absorbance $(p<0.05)$ in groups treated with CDMP-2. Data is presented as mean $\pm S D$ and results are derived from three individual experiments each performed in quintuplicate. * indicates significant difference compared with the control group of the same time point $(p<0.05)$.
CDMP-2 was used as a stimulant, there were significant increases in the mean \%area stained on the underside of Boyden chamber membranes at all concentrations $(n=6, p<0.05)$, indicative of increased cell migration. Cells stimulated with $200 \mathrm{ng} / \mathrm{ml}$ of CDMP-2 yielded the highest, a $\sim 3$-fold increase $(\mathrm{p}=0.013)$ in \%area compared to the control (Figure $2 \mathrm{~A} \& \mathrm{~B})$. There was a positive trend between \%area and CDMP-2 concentration as a stimulant, indicative of a dose response.

When CDMP-2 was used as an attractant, the highest \%area was observed at $200 \mathrm{ng} / \mathrm{ml}$ with a $>2$-fold increase compared to the control $(\mathrm{p}=0.027)$ (Figure $2 \mathrm{~B})$, with the results again demonstrating a doseresponse trend. However, CDMP-2 as an attractant yielded less migration than when present as a stimulant at all concentrations (Figure 2A\& B).

To investigate the potential involvement of known migration marker genes, we analysed the effect of mRNA expression of the cells following culture with CDMP-2. We observed significant increases in expression of SNAI2 (60\% increase, $\mathrm{p}=0.051)$ and $\beta$ integrin (30\% increase, $\mathrm{p}=0.047) \mathrm{mRNA}$ when cells were cultured with $200 \mathrm{ng} / \mathrm{ml}$ of CDMP-2, compared to the control. However, no significant differences in the expression of these markers were observed at $100 \mathrm{ng} / \mathrm{ml}$ of CDMP-2 (Figure 3).

\section{CDMP-2 stimulates proteoglycan production}

Alcian blue staining and ImageJ analysis were used to determine total PGs production in C28/I2 cells cultured with CDMP-2 (100ng/ml). A significantly $(\mathrm{n}=5, \mathrm{p}=0.048)$ higher percentage area of positive staining was detected (Figure 4A), with an almost 8 -fold increase compared to the control (Figure 4B).

Immunocytochemical staining of C28/I2 cells was used to model CDMP-2 stimulation of functional aggrecan protein expression. Compared to the control $(0 \mathrm{ng} / \mathrm{ml})$, there was a $50 \%$ increase in the \%area of staining at $100 \mathrm{ng} / \mathrm{ml} \mathrm{CDMP}-2(\mathrm{n}=5, \mathrm{p}=0.021)$ and a $130 \%$ increase with a $200 \mathrm{ng} / \mathrm{ml}$ dose $(\mathrm{n}=5, \mathrm{p}=0.003)$ (Figure 4C\&D). Two doses were used in this experiment to establish a dose-response. We also analysed the expression of aggrecan mRNA in CDMP-2 stimulated C28/I2 cells using semi-quantitative PCR, de- 
tecting an increase of $60 \%$ in aggrecan expression relative to housekeeping genes at $200 \mathrm{ng} / \mathrm{ml}$ of CDMP-2 when compared to the control (0ng/ml CDMP-2) (data not shown). The increased expression of aggrecan demonstrated a dose-related pattern

A.

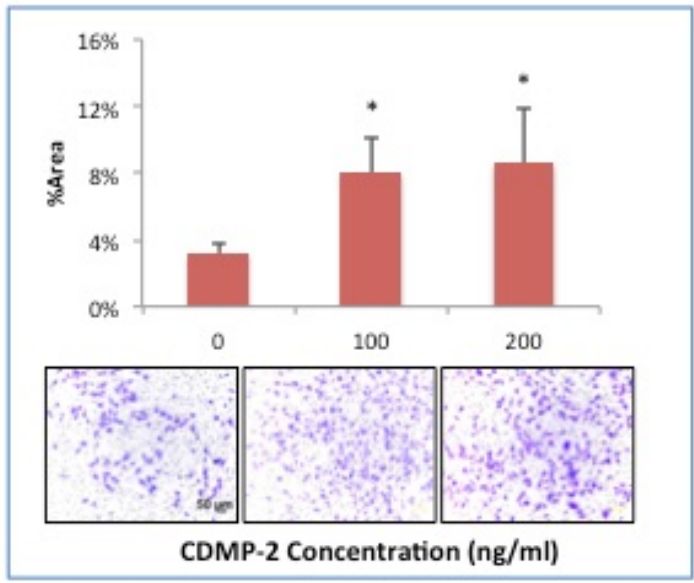

B.

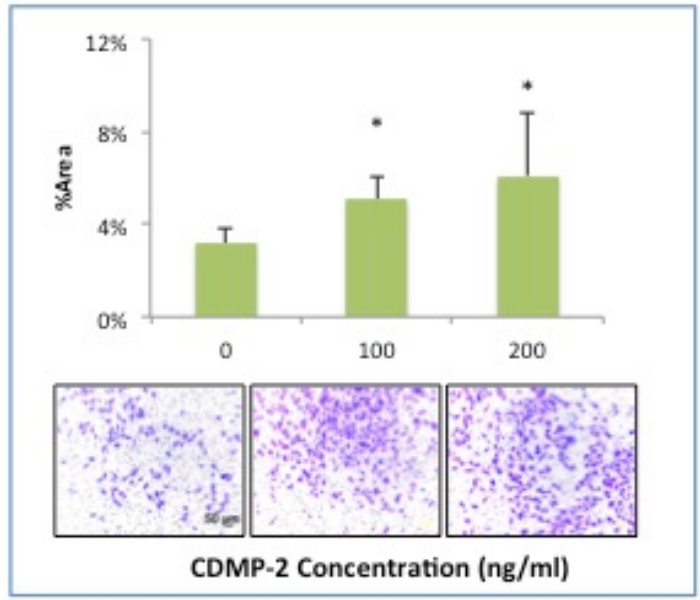

Fig. 2. A) Effect of CDMP-2 on $\mathrm{C} 28 / \mathrm{Cl} 2$ cell migration capacity. The presence of CDMP-2 in the upper chamber of a transwell plate significantly increased cell migration as observed with Boyden Chamber assay with varying doses at 45 hours, compared to cultured alone. (Top panel) Graphical representation of Crystal Violet-stained cells after migration; percentage of area staining was calculated with Image-J software. (Bottom panel) Representative microscopic images of Boyden Chamber filters mounted on slides. Varying concentrations of CDMP-2 were used. All groups with CDMP-2 as a stimulant had significantly higher \%area of staining compared to control $(p<0.05)$. Data is presented as mean \pm standard deviation (SD). * indicates significant difference compared with control ( $p<0.05)$. B) Effect of CDMP-2 on $\mathrm{C} 28 / \mathrm{Cl} 2$ cell migration capacity. The presence of CDMP-2 in the bottom chamber of a transwell plate significantly increased cell migration as observed with Boyden Chamber assay with varying doses at 45 hours, compared to cultured alone. (Tope panel) Graphical representation of Crystal Violet -stained cells after migration; percentage of area staining was calculated with Image-J software. (Bottom panel) Representative microscopic images of Boyden Chamber filters mounted on slides. Varying concentrations of CDMP-2 were used. As an attractant, doses of $200 \mathrm{ng} / \mathrm{ml}$ and $300 \mathrm{ng} / \mathrm{ml}$ of CDMP-2 resulted in significantly higher \% area of staining compared to control $(p<0.05)$. Data is presented as mean \pm standard deviation (SD). * indicates significant difference compared with control $(p<0.05)$.
(Figure 4E).

CDMP-2 stimulates collagen expression and production

As a further indicator of chondrogenic potential, we
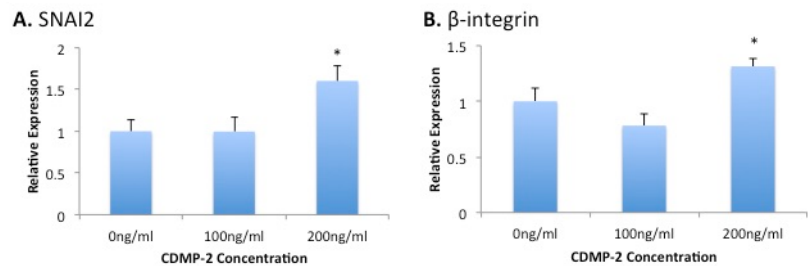

Fig. 3. Gene expression analysis of migration markers in C28/12 cells under CDMP-2 stimulation. Represented as CDMP-2 concentration ( $x$-axis) against normalised relative expression ( $y$-axis). Relative expression was calculated using RT-PCR analysis, with 3 reference genes (GAPDH, B2M, HPRT1). Values were normalised to the control $(0 \mathrm{ng} / \mathrm{ml})$. Each reaction was repeated 4-times, values represented as mean + SEM. * indicates significant difference compared to control group $(p<0.05)$. A) SNAI2; B) $\beta$-integrin.
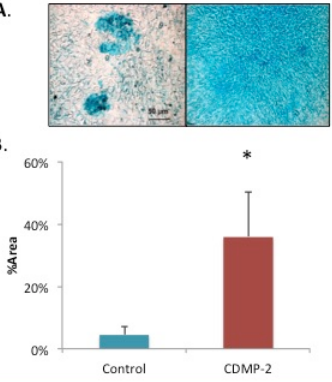

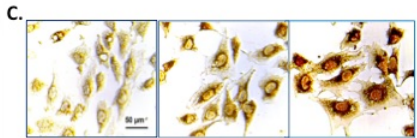

D.

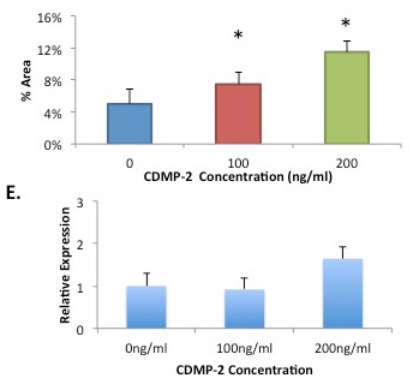

Fig. 4. A) Microscopic view of $\mathrm{C} 28 / 12$ cells with Alcian blue staining Stained cells with GAG production is observed to be more prominent in the group treated with CDMP-2 (right) than the control group (left). B) Effect of CDMP-2 (100ng/ml) on proteoglycan production as observed with Alcian blue staining assay and ImageJ analysis. Mean \%area of staining is 7.8 times more in the CDMP-2 treated group than the control group $(p=0.048)$. Data is presented as mean \pm standard deviation (SD) with each bar representing the combined data from three individual experiments. C) Microscopic view of C28/I2 cells of immuno-staining with primary antibody for aggrecan. Strong brown staining is observed in cells stimulated with CDMP-2 of $100 \mathrm{ng} / \mathrm{ml}$ (middle panel) and $200 \mathrm{ng} / \mathrm{ml}$ (right panel) than with control (left panel). The figure is a representative of cultured from three independent samples (original magnification: X400). D) Mean \% area of staining is used to quantify aggrecan immuno-staining of C28/12 cells. Under the influence of CDMP-2 of varying concentrations, cells increased functional production of aggrecans by $50 \%$ at $100 \mathrm{ng} / \mathrm{ml}$ and $130 \%$ at $200 \mathrm{ng} / \mathrm{ml}$ compared to the control $(p<0.05)$. Data is presented as mean \pm standard deviation (SD). E) Gene expression analysis of aggrecan in C28/ I 2 cells under CDMP-2 stimulation. Represented as CDMP-2 concentration (x-axis) against normalised relative expression (y-axis). Relative expression was calculated using RT-PCR analysis, with 3 reference genes (GAPDH, $\mathrm{B} 2 \mathrm{M}$ and HPRT1). Values were normalised to the control $(\mathrm{Ong} / \mathrm{ml})$. Each reaction was repeated 4-times, values represented as mean + SEM. Results were not statistically significant $(p<0.05)$. * indicates significant difference compared with the control group $(p<0.05)$.

Downloaded from http://ijssurgery.com/ by guest on April 26, 2023 
analysed the production of collagen by C28/I2 cells in response to CDMP-2. Total collagen synthesis was measured using $\left[{ }^{3} \mathrm{H}\right]$-proline incorporation assay of cells cultured with/without $100 \mathrm{ng} / \mathrm{ml}$ of CDMP-2 for 48 hours. There was a 3 -fold increase $(\mathrm{p}=0.014)$ in collagen synthesis when cells were treated with CDMP-2 compared to cells treated with growth medium alone (Figure 5). This is supported by gene expression analysis of various collagens in CDMP-2 treated C28/I2 cells where stimulation with 100ng/ $\mathrm{ml}$ of CDMP- 2 caused a $40 \%$ increase in expression of type II collagen ( $p=0.018)$, compared to the control (Figure 6). There was also a 5.5-fold increase of type $X$ collagen $(p=0.099)$ and 3.5-fold increase of type XXVII collagen $(\mathrm{p}=0.254)$ at this concentration of CDMP-2, though the results were not statistically significant.

Likewise, immunocytochemistry of C28/I2 cells with primary antibody for type II collagen suggested a dose dependent increase in expression of type II collagen protein with CDMP-2 stimulation. A $100 \mathrm{ng} / \mathrm{ml}$ dose of CDMP-2 induced a $60 \%$ increase in \%area of staining $(n=5, p=0.023)$ compared to control (Figure 7A). We further investigated with a $200 \mathrm{ng} / \mathrm{ml}$ dose, which caused a $70 \%$ increase $(\mathrm{n}=5$, $\mathrm{p}=0.002$ ) (Figure 7B). No brown staining was detected in the negative control slides with the omission of the primary antibody (results not shown). However, when we performed PCR to confirm this finding, it

A.

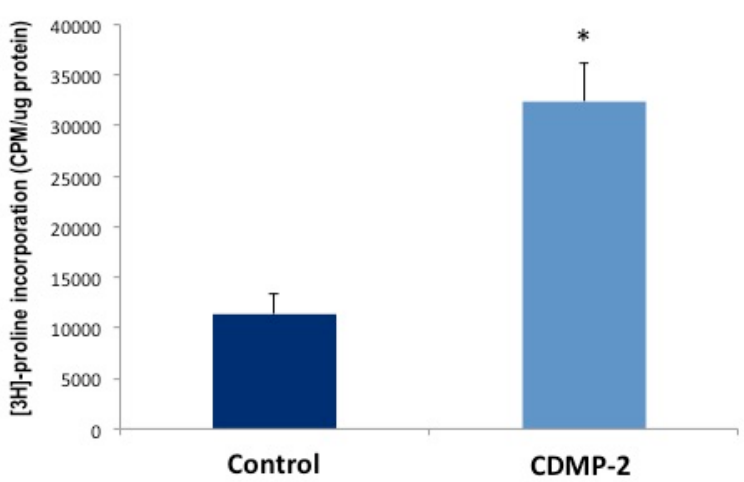

Fig. 5. Effect of CDMP-2 $(100 \mathrm{ng} / \mathrm{ml})$ on total collagen production measured with $[3 \mathrm{H}]$-proline incorporation assay. Total collagen synthesis is 3 times more in the CDMP-2 treated group than the control group $(p<0.05)$. Data is presented as mean \pm standard deviation (SD) with each bar representing combined data from three individual experiments.

was observed that at $200 \mathrm{ng} / \mathrm{ml}$ of CDMP-2, type II collagen expression was not significantly different from that of control (Figure 6B)

BMP receptor expression in CDMP-2 treated chondrocytic cells

To further investigate the mechanism of CDMP-2
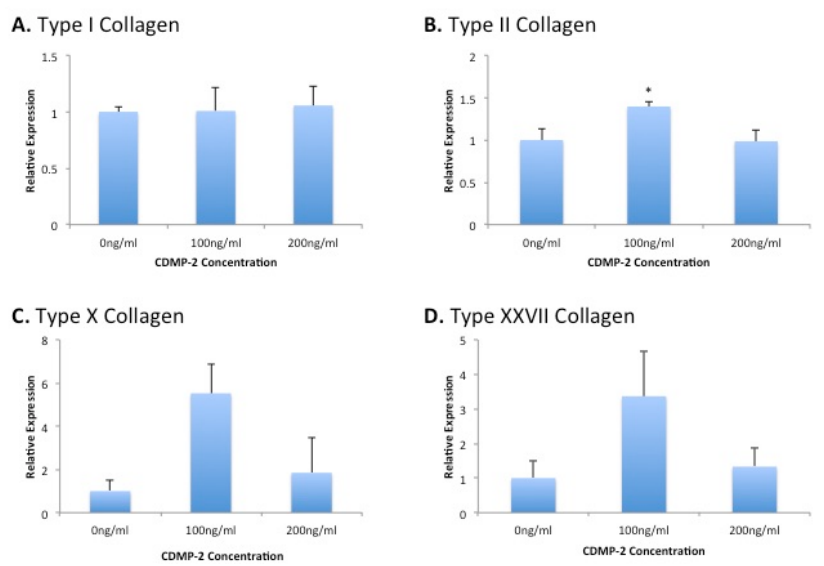

Fig. 6. Gene expression analysis of chondrocytic markers and receptors in C28/I2 cells under CDMP-2 stimulation ( $0 \mathrm{ng} / \mathrm{ml}, 100 \mathrm{ng} / \mathrm{ml}, 200 \mathrm{ng} / \mathrm{ml}$ ) for 48 hours. Represented as CDMP-2 concentration ( $x$-axis) against normalised relative expression (y-axis). Relative expression was calculated using RT-PCR analysis, with 3 reference genes. Values were normalised to the control $(0 \mathrm{ng} / \mathrm{ml})$. Each reaction was repeated 4-times, values represented as mean + SEM. * indicates significant difference compared with the control group $(p<0.05)$. A) Type I Collagen; B) Type II Collagen; C) Type X Collagen; D) Type XXVII Collagen.

A.

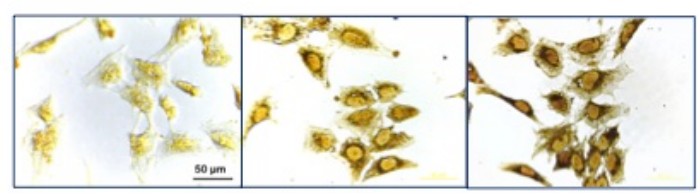

B.

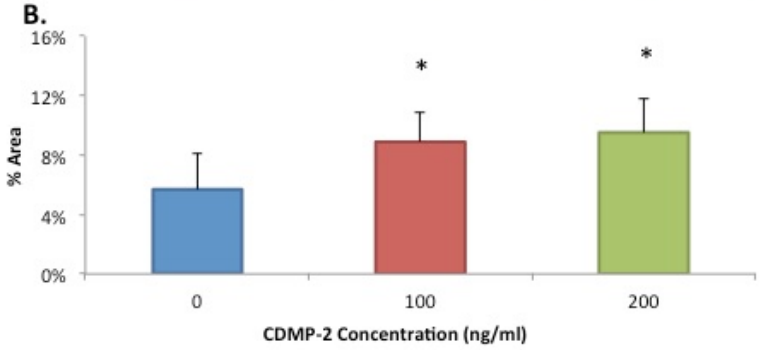

Fig. 7. A) Microscopic view ( $x 40$ magnification) of $C 28 / 12$ cells of immuno-staining for type II collagen. Strong brown staining is observed in cells stimulated with CDMP-2 of $200 \mathrm{ng} / \mathrm{ml}$ (right panel) and $100 \mathrm{ng} / \mathrm{ml}$ (middle panel) than with control (left panel). The figure is a representative of culture from three independent samples. B) Protein expression of type II collagen production of C28/I2 cells under CDMP- 2 influence,

demonstrated using immunocytochemistry and ImageJ analysis. Data presented as mean \pm standard deviation (SD). $N=5$. * indicates significant difference compared with control $(p<0.05)$. 
chondrogenic action, we measured the gene expression of related receptors in CDMP-2 stimulated C28/I2 cells at doses of $100 \mathrm{ng} / \mathrm{ml}$ and $200 \mathrm{ng} / \mathrm{ml}$. Stimulation with CDMP-2 at $200 \mathrm{ng} / \mathrm{ml}$ had statistically significant effects on the expression of BMPR-1A and BMPR-II, with a 40\% ( $\mathrm{p}=0.02)$ and $30 \%$ $(\mathrm{p}=0.02)$ increase from the control respectively (Figure 8). BMPR-IB expression was increased in response to CDMP-2 stimulation at $200 \mathrm{ng} / \mathrm{ml}$, but the data was more variable (Figure 5).

\section{Discussion}

This study demonstrates for the first time the ability of CDMP-2 to induce cell migration in a human chondrocyte cell line. The data support previous observations of enhanced cellularity at the EP-NP junction following intra-discal CDMP-2 injection in an ovine injury model and the hypothesis that cells were moving towards the NP. ${ }^{16}$ The decision of employing an immortalised cell line rather than native IVD cells for this study was based on the faster cellular turnover and reduced genetic variability of the $\mathrm{C} 28$ / I2 cells, which have been previously used to study cartilage metabolism. ${ }^{18}$ This suits our study objective to establish the biological ability of CDMP-2 to induce cell movement, in cells which resemble those of the cartilaginous endplate, with the benefit of reduced individual variability inherent in any primary cell based study. Clearly the conclusions cannot be
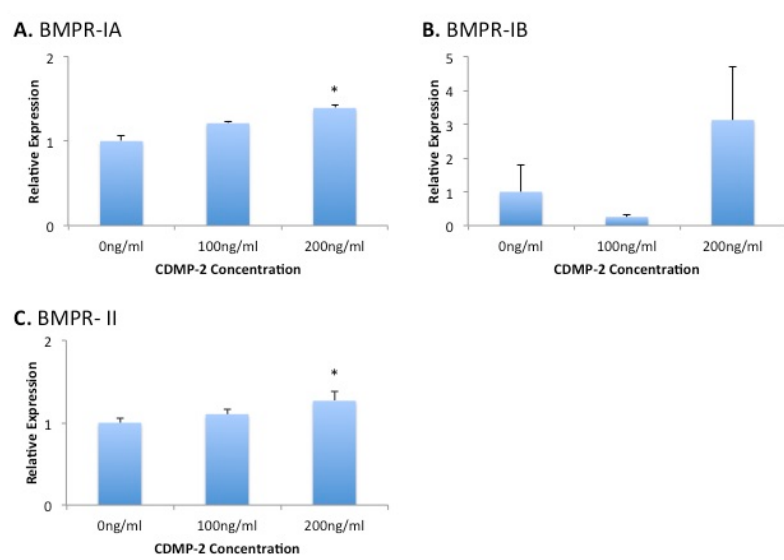

Fig. 8. Gene expression analysis of BMP receptors in C28/I2 cells under CDMP-2 stimulation. Represented as CDMP-2 concentration ( $x$-axis) against normalised relative expression ( $y$-axis). Relative expression was calculated using RT-PCR analysis, with 3 reference genes. Values were normalised to the control $(0 \mathrm{ng} / \mathrm{ml})$. Each reaction was repeated 4-times, values represented as mean + SEM. * indicates significant difference compared to control group $(p<0.05)$. A) BMPR-IA; B) BMPR-IB;C) BMPR- II. directly extrapolated to apply to primary cells, however with the principle established, further studies on the CDMP-2 induced motility of disc cells and mesenchymal progenitors is planned and will answer questions as to cell type specificity in CDMP-2 migratory response behaviour.

The current study shows that CDMP-2 indeed has the ability to induce cell motility, at least in the chondrocytic C28/I2 cell line. The Boyden chamber assays quantified cell movement in response to CDMP-2 when cells were stimulated with CDMP-2 (stimulant, 2-3 fold) or induced to move along a CDMP-2 gradient (attractant, 2-fold). These data are in keeping with previous reports of chemotactic effects in BMPs such as BMP-2, a known chemotaxisinducing growth factor. ${ }^{20}$

Interestingly, we observed a greater and more dosedependent migration response when CDMP-2 was employed as a chemo-stimulant than a chemoattractant. Two key processes, cell polarisation and gradient sensing, influence the pseudopodia formation and motility of the cells. ${ }^{21,22}$ The results here suggest that the migration of the current cell line may be more dependent on close-range CDMP-2 stimulation driving the cells to polarise than a longdistance attractant gradient, but further studies are needed to establish the mechanism of action. Such properties become significant when considering any future therapeutic use of CDMP-2 in the disc, as the injection of the molecule may be more effective in the specific location of the native cells (e.g. cartilaginous EP) than the desired final destination of the migrating cells (NP). It is also possible that responses to CDMP-2 may vary depending on the cell type. It will be particularly interesting to establish the migration of mesenchymal progenitors such as those identified in disc stem cell 'niches, ${ }^{23,24}$ in response to CDMP-2. The observed cell migration in response to CDMP-2 was accompanied by up-regulated expression of SNAI2 and $\beta$-integrin genes. Expression of human SLUG (SNAI2) gene correlates with increased invasiveness and metastases of tumours, ${ }^{25}$ while adhesion molecule beta-integrin is known to facilitate intracellular signalling in the migration of cancer cells. ${ }^{26}$ In this study, expression of these migration markers was determined in static cell cultures 
stimulated with CDMP-2, rather than in migrated cells. It would be interesting in future studies to develop a migratory cell model with which to study gene expression in CDMP-2-induced cell migration.

CDMP-2 has been suggested to regulate chondrocyte differentiation and proliferation, ${ }^{27}$ particularly in tissues delineating bone-cartilage borders. ${ }^{28,29}$ In this study we examined the effects of CDMP-2 incorporation on cellular proliferation and extracellular matrix production in a human chondrocytic cell line in vitro. The MTS assay results showed that CDMP-2 did induce cellular proliferation of C28/I2 cells (increase by $35 \%$ ) and, though limited dose response trends were observed, the proliferative effect was present through to 72 hours of stimulation. Recent data demonstrating the proliferative potential of CDMP-2 on murine MSCs ${ }^{15,30}$ and CDMP-2 expression in proliferating cartilaginous tissue ${ }^{31}$ support these data, with mouse MSCs proliferating in response to CDMP-2 for as long as 168 hours. $^{15}$

CDMP-2 was observed to have a functional chondrogenic effect, showing stimulation of proteoglycan and collagen synthesis in C28/I2 cells. The total glycosaminoglycan (GAG) content reflected in Alcian blue staining showed that cells readily produced more proteoglycans under the influence of CDMP-2, and more specifically CDMP-2 stimulation elevated aggrecan protein and mRNA levels, an important proteoglycan in disc maintenance. These data are reinforced by other investigations in our laboratory, which have demonstrated similar patterns of GAG production in human IVD cells when cultured with CDMP-2..$^{32}$ This, conversely, validates our study, as the results derived from the cell line appear to resemble the effect CDMP-2 has on endogenous disc cells. Our results are further supported by previous reports of enhanced proteoglycan production in response to in vivo CDMP-2 injection into injured ovine IVD. ${ }^{16} \mathrm{CDMP}-2$ has also reportedly enhanced mRNA levels of proteoglycans and aggrecans in mouse chondrocytic cell line MC615. ${ }^{33}$ As degenerative disc is characterized by a loss of PG, it is important and encouraging that CDMP-2 has such a potent effect on expression of these IVD extracellular matrix molecules.
CDMP-2 stimulation increased synthesis of total collagen in C28/I2 cells and up-regulated functional protein expression, which is also functionally important in any consideration of IVD matrix replenishment. Specifically, the mRNA expression of collagen type II, type X and type XXVII was observed, the ramifications of which are not yet clear. Collagen $\mathrm{XXVII}$ is a recently discovered fibrillar collagen that is hypothesized to play a role in the organization of cartilage extracellular matrix prior to endochondral ossification $^{34,35}$ Collagen $\mathrm{X}$ is also expressed at endochondral ossification, by hypertrophic chondrocytes. ${ }^{36}$ Interestingly, we have found strong CDMP-2 expression in hypertrophic chondrocytes in foetal spinal tissue, ${ }^{37}$ and its expression has been linked with the delineation of bone boundaries in developing organisms. ${ }^{28,29}$ Further studies are needed to determine the specific signaling pathway of CDMP-2 in regulating expression of specific extracellular matrix molecules both during development and in adult tissue maintenance, but the tendency for CDMP-2 to promote chondrogenic tissue renewal is encouraging from the perspective of therapeutic use in disc regeneration.

Interestingly, when investigating expression of known BMP receptors, we found that BMPR-2 and BMPR-1A were up-regulated by CDMP-2 in C28/I2 cells, suggesting their involvement in CDMP-2 signaling in chondrocytes. Previous functional studies have shown expression of BMPR-2 and BMPR-1A in a CDMP-2 stimulated mesenchymal progenitor cell line, ${ }^{30}$ but reported a functional preference for CDMP-2 binding to the BMPR-IB/BMPR-2 receptor complex rather than BMPR-IA/BMPR-2. ${ }^{38}$ There appeared to be no statistically significant upregulation of BMPR-1B in response to CDMP-2, although increased mRNA expression was measured at 200ng/mL. Interestingly, solid phase protein affinity studies have indicated CDMP-2 has a stronger interaction with BMPR-IB than BMPR-IA. ${ }^{39}$ With a large number of BMP molecules all utilizing the same receptor complex components to trigger intracellular signaling, receptor usage by BMPs has been proposed as a significant means of controlling the effects of these powerful morphogens. ${ }^{40}$ Further detailed work will be necessary to understand these factors in disc cells. 
While multiple molecules have demonstrated proliferative and chondrogenic effects on existing cells, ${ }^{14,41}$ what remains as an obstruction to their use as therapies is the lack of cells in the NP of a severely degenerated disc, making the discovery of a signalling molecule with chemotactic potential for cells residing in the adjacent EP to be an attractive therapeutic option. In biological terms, two aspects must be established in order to illustrate the chemotactic potential of CDMP-2 in the IVD: 1 ) the ability of CDMP-2 to bind to surface receptors to induce cell motility, and 2) the ability of the target cells, in this case native EP cells (either mature or progenitor), to migrate under a CDMP-2-induced chemotactic gradient. Ex vivo animal IVD models have highlighted the migration of EP cells and bone marrow-derived stem cells under growth factor stimulation. ${ }^{42,43}$ This study provides strong supporting evidence for CDMP-2 induced cell motility. Elevated cellular chemotactic markers in response to CDMP-2 seen in our study strongly suggest CDMP-2 induces a metabolically active process of cell migration, possibly mediated by BMPR-2 and BMPR-1A receptors. Moreover, the proliferative and chondrogenic pattern of CDMP-2 on our cell line suggests similar chemotactic and regenerative effects may be observed in native disc tissue.

Notably, the major limitation of this study is the use of an immortalised cell line, with results that cannot be directly extrapolated to native EP chondrocytes. However, cell lines derived from human chondrocytes have been widely used to investigate the mechanisms involved in chondrocytic tissues (e.g. articular cartilage, EP), and have served as models to understand molecular signalling pathways and efficacy of novel therapies. ${ }^{44,45}$ In order to investigate the potential ability of CDMP-2 to stimulate disc chondrocyte (EP cells) migration, the cell line we used, C28/ I2, reflects the major characteristics of this particular type of disc cells we wanted to investigate. ${ }^{18}$ The results from our study provide a rational basis for more focused investigations into the chemotactic actions of CDMP-2 on native discs. Specifically, studies into how CDMP-2 affects the receptor and intracellular pathways of cartilaginous EP cells are worthwhile to confirm the chemotactic potential of CDMP-2 demonstrated in this study.

\section{Conclusion}

The current study highlights the ability of CDMP-2 to both stimulate chondrocytes to mobilise and attract cell movement along a chemotactic gradient. In addition, it has reinforced many previous investigations in indicating the chondrogenic potential CDMP-2 in the stimulation of cell proliferation, and synthesis of collagen and proteoglycan at a functional and transcriptional level. Further examination of CDMP-2's biological properties on EP of the IVD both in vivo and in vitro are necessary, which will show a further dimension of possibility for this molecule in application to biological tissue regeneration therapies.

\section{Acknowledgement}

The authors would like to thank Spine Service, St. George Hospital, Sydney, Australia for support and funding of this study. In addition we gratefully acknowledge Dr. Mary B. Goldring for the kind gift of the C28/I2 human chondrocytic cell line used in this study. The study was performed at the St George Orthopaedic Research Institute, Sydney.

\section{References}

1. Andersson GB: Epidemiological features of chronic low-back pain. Lancet 1999, 354:581-585.

2. Bressler HB, Keyes WJ, Rochon PA, Badley E: The prevalence of low back pain in the elderly. A systematic review of the literature. Spine 1999, 24:1813-1819.

3. Hicks GE, Morone N, Weiner DK: Degenerative lumbar disc and facet disease in older adults: prevalence and clinical correlates. Spine 2009, 34:1301-1306.

4. Murray CJ, Vos T, Lozano R, Naghavi M, Flaxman AD, Michaud C, Ezzati M, Shibuya K, Salomon JA, Abdalla $S$, et al: Disability-adjusted life years (DALYs) for 291 diseases and injuries in 21 regions, 1990-2010: a systematic analysis for the Global Burden of Disease Study 2010. Lancet 2012, 380:2197-2223.

5. Williams FM, Sambrook PN: Neck and back pain and intervertebral disc degeneration: role of 
occupational factors. Best practice \& research Clinical rheumatology 2011, 25:69-79.

6. Inoue N, Espinoza Orias AA: Biomechanics of intervertebral disk degeneration. The Orthopedic clinics of North America 2011, 42:487-499, vii.

7. Hunter CJ, Matyas JR, Duncan NA: Cytomorphology of notochordal and chondrocytic cells from the nucleus pulposus: a species comparison. Journal of anatomy 2004, 205:357-362.

8. Luoma K, Riihimaki H, Luukkonen R, Raininko $\mathrm{R}$, Viikari-Juntura E, Lamminen A: Low back pain in relation to lumbar disc degeneration. Spine 2000, 25:487-492.

9. Morgan FP, King T: Primary instability of lumbar vertebrae as a common cause of low back pain. The Journal of bone and joint surgery British volume 1957, 39-B:6-22.

10. Chan SC, Gantenbein-Ritter B: Intervertebral disc regeneration or repair with biomaterials and stem cell therapy--feasible or fiction? Swiss medical weekly 2012, 142:w13598.

11. Valdes MA, Thakur NA, Namdari S, Ciombor DM, Palumbo M: Recombinant bone morphogenic protein-2 in orthopaedic surgery: a review. Archives of orthopaedic and trauma surgery 2009, 129:1651-1657.

12. Tian H, Yang S, Xu L, Zhang Y, Xu W: Chondrogenic differentiation of mouse bone marrow mesenchymal stem cells induced by cartilagederived morphogenetic protein-2 in vitro. Journal of Huazhong University of Science and Technology Medical sciences = Hua zhong ke ji da xue xue bao Yi xue Ying De wen ban = Huazhong keji daxue xuebao Yixue Yingdewen ban 2007, 27:429-432.

13. Gu Y, Wang Y, Dai H, Lu L, Cheng Y, Zhu W: Chondrogenic differentiation of canine myoblasts induced by cartilage-derived morphogenetic protein-2 and transforming growth factor-betal in vitro. Molecular medicine reports 2012, 5:767-772.

14. Zhang Y, Anderson DG, Phillips FM, Thonar EJ, He TC, Pietryla D, An HS: Comparative effects of bone morphogenetic proteins and Sox 9 overexpression on matrix accumulation by bovine anulus fibrosus cells: implications for anular repair. Spine 2007, 32:2515-2520.

15. Dorman LJ, Tucci $M$, Benghuzzi $H$ : In vitro effects of bmp-2, bmp-7, and bmp-13 on prolifera- tion and differentation of mouse mesenchymal stem cells. Biomedical sciences instrumentation 2012, 48:81-87.

16. Wei A, Williams LA, Bhargav D, Shen B, Kishen T, Duffy N, Diwan AD: BMP13 prevents the effects of annular injury in an ovine model. International journal of biological sciences 2009, 5:388-396.

17. Zhou FY, Wei AQ, Diwan AD: An Overview of Intervertebral Disc Degeneration Therapies and an Evaluation of the Chondrogenic and Chemotactic Potential of CDMP-2. In Journal of Biomimetics, Biomaterials and Biomedical Engineering. Trans Tech Publ; 2013: 97-118.

18. Claassen H, Schicht M, Brandt J, Reuse K, Schädlich R, Goldring MB, Guddat SS, Thate A, Paulsen F: C-28/I2 and T/C-28a2 chondrocytes as well as human primary articular chondrocytes express sex hormone and insulin receptors-Useful cells in study of cartilage metabolism. Annals of Anatomy-Anatomischer Anzeiger 2011, 193:23-29.

19. Gutiérrez ML, Guevara J, Barrera LA: Semiautomatic grading system in histologic and immunohistochemistry analysis to evaluate in vitro chondrogenesis. Universitas Scientiarum 2012, 17:167-178.

20. Fiedler J, Roderer G, Gunther KP, Brenner RE: BMP-2, BMP-4, and PDGF-bb stimulate chemotactic migration of primary human mesenchymal progenitor cells. Journal of cellular biochemistry 2002, 87:305-312.

21. Vorotnikov AV: Chemotaxis: movement, direction, control. Biochemistry Biokhimiia 2011, 76:1528-1555.

22. Cai H, Devreotes PN: Moving in the right direction: how eukaryotic cells migrate along chemical gradients. Seminars in cell \& developmental biology 2011, 22:834-841.

23. Henriksson HB, Svala E, Skioldebrand E, Lindahl A, Brisby H: Support of concept that migrating progenitor cells from stem cell niches contribute to normal regeneration of the adult mammal intervertebral disc: a descriptive study in the New Zealand white rabbit. Spine 2012, 37:722-732. 24. Henriksson H, Thornemo M, Karlsson C, Hagg O, Junevik K, Lindahl A, Brisby H: Identification of cell proliferation zones, progenitor cells and a po- 
tential stem cell niche in the intervertebral disc region: a study in four species. Spine (Phila Pa 1976) 2009, 34:2278-2287.

25. Olmeda D, Montes A, Moreno-Bueno G, Flores JM, Portillo F, Cano A: Snail and Snai2 collaborate on tumor growth and metastasis properties of mouse skin carcinoma cell lines. Oncogene 2008, 27:4690-4701.

26. Hood JD, Cheresh DA: Role of integrins in cell invasion and migration. Nature Reviews Cancer 2002, 2:91-100.

27. Erlacher L, Ng CK, Ullrich R, Krieger S, Luyten FP: Presence of cartilage-derived morphogenetic proteins in articular cartilage and enhancement of matrix replacement in vitro. Arthritis and rheumatism 1998, 41:263-273.

28. Clendenning DE, Mortlock DP: The BMP ligand Gdf6 prevents differentiation of coronal suture mesenchyme in early cranial development. PLoS One 2012, 7:e36789.

29. Tassabehji M, Fang ZM, Hilton EN, McGaughran J, Zhao Z, de Bock CE, Howard E, Malass M, Donnai D, Diwan A, et al: Mutations in GDF6 are associated with vertebral segmentation defects in Klippel-Feil syndrome. Human Mutation 2008, 29:1017-1027.

30. Nochi H, Sung JH, Lou J, Adkisson HD, Maloney WJ, Hruska KA: Adenovirus mediated

BMP-13 gene transfer induces chondrogenic differentiation of murine mesenchymal progenitor cells. Journal of bone and mineral research : the official journal of the American Society for Bone and Mineral Research 2004, 19:111-122.

31. Williams LA, Bhargav D, Diwan AD: Unveiling the bmp13 enigma: redundant morphogen or crucial regulator? International journal of biological sciences 2008, 4:318-329.

32. Gulati TC, S. A.; Wei, A. Q.; Diwan, A. D.: Localisation of bone morphogenetic protein 13 in human intervertebral disc and its molecular and functional effects in vitro in 3D culture. In Book Localisation of bone morphogenetic protein 13 in human intervertebral disc and its molecular and functional effects in vitro in $3 D$ culture (Editor ed.^eds.). City: Orthopaedic Research Institute, St George Hospital Clinical School, University of New South Wales, Sydney, Australia; 2014.
33. Li J, Kim KS, Park JS, Elmer WA, Hutton WC, Yoon ST: BMP-2 and CDMP-2: stimulation of chondrocyte production of proteoglycan. Journal of orthopaedic science : official journal of the Japanese Orthopaedic Association 2003, 8:829-835.

34. Plumb DA, Ferrara L, Torbica T, Knowles L, Mironov Jr A, Kadler KE, Briggs MD, Boot-

Handford RP: Collagen XXVII organises the pericellular matrix in the growth plate. PloS one 2011, 6:e29422.

35. Hjorten R, Hansen U, Underwood RA, Telfer HE, Fernandes RJ, Krakow D, Sebald E, Wachsmann-Hogiu S, Bruckner P, Jacquet R: Type XXVII collagen at the transition of cartilage to bone during skeletogenesis. Bone 2007, 41:535-542. 36. Gu J, Lu Y, Li F, Qiao L, Wang Q, Li N, Borgia JA, Deng Y, Lei G, Zheng Q: Identification and characterization of the novel Col10al regulatory mechanism during chondrocyte hypertrophic differentiation. Cell death $\&$ disease 2014, 5:e1469.

37. Wei A, Shen B, Williams LA, Bhargav D, Gulati T, Fang Z, Pathmanandavel S, Diwan AD. Expression of growth differentiation factor 6 in the human developing fetal spine retreats from vertebral ossifying regions and is restricted to cartilaginous tissues. J Orthop Res. 2015 Jul 17.

38. Erlacher L, McCartney J, Piek E, Dijke PT, Yanagishita M, Opermann H, Luyten FP: Cartilage derived morphogenic proteins and osteogenic protein-1 differentially regulate osteogenesis. Journal of Bone and Mineral Research 1998, 13:383-392.

39. Berasi SP, Varadarajan U, Archambault J, Cain M, Souza TA, Abouzeid A, Li J, Brown CT, Dorner AJ, H JS, Jelinsky SA: Divergent activities of osteogenic BMP2, and tenogenic BMP12 and BMP13 independent of receptor binding affinities. Growth factors 2011, 29:128-139.

40. Mueller TD, Nickel J: Promiscuity and specificity in BMP receptor activation. FEBS Lett 2012, 586:1846-1859.

41. Chujo T, An HS, Akeda K, Miyamoto K, Muehleman C, Attawia M, Andersson G, Masuda K: Effects of growth differentiation factor-5 on the intervertebral disc--in vitro bovine study and in vivo rabbit disc degeneration model study. Spine 2006, 31:2909-2917.

42. Kim KW, Ha KY, Lee JS, Nam SW, Woo YK, 
Lim TH, An HS: Notochordal cells stimulate migration of cartilage end plate chondrocytes of the intervertebral disc in in vitro cell migration assays. The spine journal : official journal of the North American Spine Society 2009, 9:323-329.

43. Illien-Junger S, Pattappa G, Peroglio M, Benneker LM, Stoddart MJ, Sakai D, Mochida J, Grad S, Alini M: Homing of mesenchymal stem cells in induced degenerative intervertebral discs in a whole organ culture system. Spine 2012, 37:1865-1873.

44. Laura ACADC, Nilssona AO: Methods to study cartilage and bone development. Cartilage and Bone Development and Its Disorders 2011, 21:52-66.

45. Steinecker-Frohnwieser B, Weigl L, Kullich W, Lohberger B: The disease modifying osteoarthritis drug diacerein is able to antagonize pro inflammatory state of chondrocytes under mild mechanical stimuli. Osteoarthritis and Cartilage 2014,
22:1044-1052.

\section{Disclosures}

There are no competing interests of any relevant parties involved in this study.

\section{Corresponding Author}

Dr. Ashish Diwan, Orthopaedic Research Institute and Department of Orthopaedic Surgery, St George Hospital, Sydney, NSW 2217, Australia.

a.diwan@spine-service.org

Published 22 October 2015.

This manuscript is generously published free of charge by ISASS, the International Society for the Advancement of Spine Surgery. Copyright @ 2015 ISASS. To see more or order reprints or permissions, see http://ijssurgery.com. 